\title{
Trwałość zmęczeniowa najstarszych spawanych mostów w Polsce w świetle badań
}

\author{
Fatigue life of the oldest welded bridges in Poland \\ in the light of research
}

\section{Streszczenie}

Procedura oceny trwałości zmęczeniowej jest jedną z najistotniejszych w kompleksowej ocenie nośności i trwałości mostów spawanych eksploatowanych przez długi okres czasu. W trakcie badań tych mostów stwierdzono w wielu złączach doczołowych istnienie niezgodności spawalniczych (karbów) z pęknięciami w spoinach czołowych włącznie. Referat jest próbą rekapitulacji wniosków z wieloletnich badań tych konstrukcji. Badania dotyczyły terenowych badań rentgenograficznych złączy doczołowych tych mostów oraz laboratoryjne badania zmęczeniowe 4 typów spoin czołowych, które w nich występują. Badania te wraz z analizą wytrzymałościową konstrukcji nośnej pozwoliły oszacować żywotność poszczególnych obiektów.

Słowa kluczowe: mosty stalowe; złącza spawane; zmęczenie stali

\begin{abstract}
The procedure for the assessment of fatigue life is one of the most important in the comprehensive assessment of capacity and durability of welded bridges exploited for a long period of time. In the study of these bridges it was found in a number of butt joints the existence of imperfections (notches) with cracks in welds leading inclusive. The paper is an attempt to recapitulate the conclusions of many years' research of these structures. The study concerned field studies X-ray butt these bridges and laboratory fatigue tests of 4 types butt welds, in which they occur. These studies, together with the strength analysis of the supporting structure made it possible to estimate the lifetime of individual objects.
\end{abstract}

Keywords: steel bridges; welded joints; steel fatigue

\section{Wstęp}

W ostatnich latach w wielu państwach przyjęto nową probabilistyczną ocenę nośności mostów eksploatowanych, omówioną w [1]. Jest to metoda rozdzielonych wykalibrowanych współczynników bezpieczeństwa o obniżonych wymaganiach w stosunku do nowo projektowanych konstrukcji, jak i wymagań w kwestii okresu dalszej eksploatacji obiektu.

Jednocześnie ukazały się zalecenia europejskiej procedury oceny trwałości zmęczeniowej istniejącej konstrukcji kompatybilnej z nowymi normami służącymi do projektowania konstrukcji stalowych [2], przedstawione na rysunku 1.

Przydatnymi w tej analizie mogą być informacje pozyskane z badań starych obiektów mostowych na temat parametrów materiałowych oraz odpowiedzi konstrukcji na obciążenia użytkowe. Artykuł jest próbą rekapitulacji wniosków z prowadzonych przez autora badań odnośnie stanu zagrożenia mostów historycznych zmęczeniem.

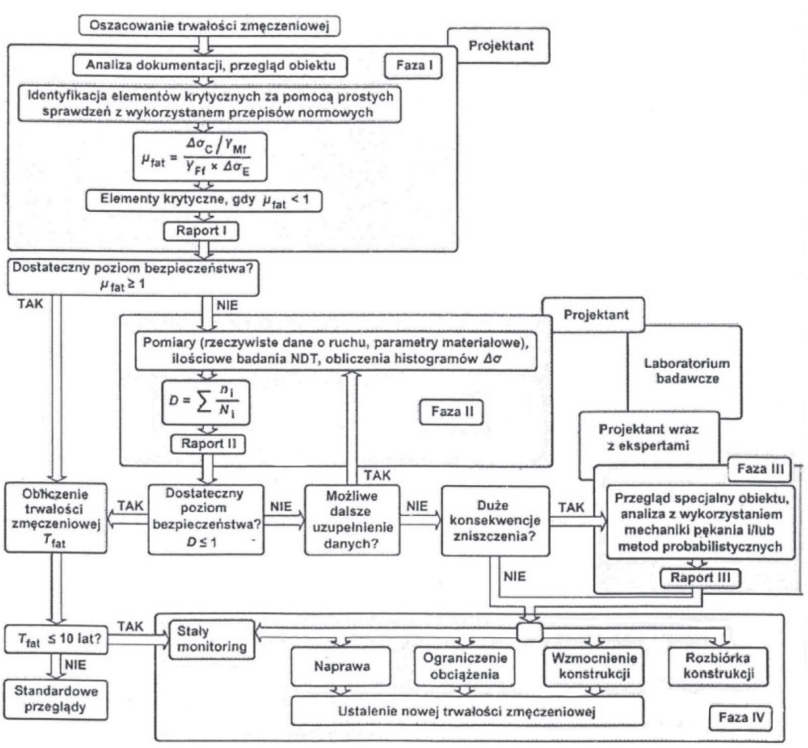

Rys. 1. Algorytm oceny trwałości zmęczeniowej istniejącej konstrukcji stalowej według [2]

Fig. 1. Algorithm assessment of the fatigue life of the existing steel structure according to [2]

Dr hab. inż. Bernard Wichtowski, em. prof. ZUT - Zachodniopomorski Uniwersytet Technologiczny w Szczecinie.

Autor korespondencyjny/Corresponding author: marekw@zut.edu.pl 


\section{Zagadnienia materiałowe starych konstrukcji mostów stalowych}

W wyniku wieloletniej eksploatacji konstrukcja mostu stalowego podlega tzw. starzeniu funkcjonalnemu, a sama stal starzeniu strukturalnemu. Mechanizm starzenia wyjaśnia się za pomocą klasycznej teorii wydzieleń lub nowszej teorii blokowania dyslokacji $[3,4]$. Poziomem porównawczym zmian właściwości materiałowych $\mathrm{w}$ trakcie eksploatacji jest symulacja wyjściowej budowy materiału za pomocą wyżarzania normalizującego. Autor artykułu wygrzewał próbki w temperaturze $930^{\circ} \mathrm{C}$ przez jedną godzinę i studził na powietrzu. Uzyskuje się w tym przypadku najmniejszą możliwą w tej stali wielkość ziarna. Jest to czynnik zwiększający granicę plastyczności i obniżający temperaturę przejścia stali w stan kruchości $[5,6]$.

Te zmiany struktury znajdują swoje odzwierciedlenie przede wszystkim w zmianach udarności materiału - rysunek 2. Na rysunku przedstawiono wyniki badań udarnościowych, w temperaturze $-20{ }^{\circ} \mathrm{C}, 9$ gatunków stali z 8 mostów wybudowanych w latach 1875-1938. Badano dwa rodzaje próbek: próbki starzone samorzutnie i próbki normalizowane. Badana stal wszystkich mostów w stanie poeksploatacyjnym, starzonym ma bardzo małą wartość pracy łamania KV. Aktualnie stwierdzona wartość KV wynosi jedynie od 4 do 12 J. Zależność ta dotyczy wszystkich stali niezależnie od zawartości węgla od 0,016 do 0,258\%.

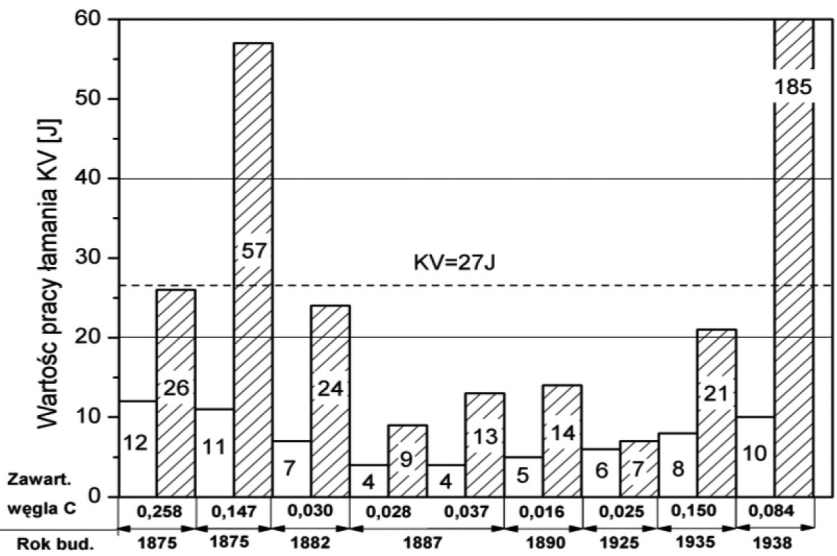

Rys. 2. Wartość pracy łamania KV stali mostów w temperaturze $-20^{\circ} \mathrm{C}$ dla próbek starzonych i normalizowanych (słupki zakreskowane)

Fig. 2. The value of breaking work $\mathrm{KV}$ of bridge steel at $-20^{\circ} \mathrm{C}$ for samples aged and normalized (hatched bars) structure according to [2]

Stan taki świadczy o kruchości materiału i jest szczególnie niebezpieczny, jeżeli występuje w obszarach spiętrzenia naprężeń, na przykład wokół niezgodności spawalniczych w spoinach - rysunek 3. Niezgodności są inicjatorami pękania, gdy obciążenie osiągnie określoną wartość krytyczną. Największą koncentrację naprężeń $\sigma_{x}$ wywołują niezgodności spawalnicze (NS) elipsoidalne oraz NS podłużne z eliptycznym przekrojem poprzecznym. Dla tych dwóch grup NS gradient zmiany maksymalnego naprężenia rośnie ze zmniejszaniem się wielkości promienia krzywizny o największej ostrości kształtu NS. Przykładowo dla tych NS o charakterystyce kształtowej $\mathrm{t} / \rho=100$, wartość współczynnika kształtu dla u = 1 wynosi 13,6 i 21,0 (por. rys. 3). Natomiast dla NS kulistych o małym stopniu koncentracji - III klasa ostrości, wartość naprężeń jest niezależna od wielkości niezgodności i wynosi $\sigma_{x}=2,04 \mathrm{p}$.

Naprężenia rozciągające $\mathrm{w}$ obecności karbu mogą być wynikiem obciążeń zewnętrznych, naprężeń własnych lub obu jednocześnie. Zwykle w spoiwie i jej sąsiedztwie

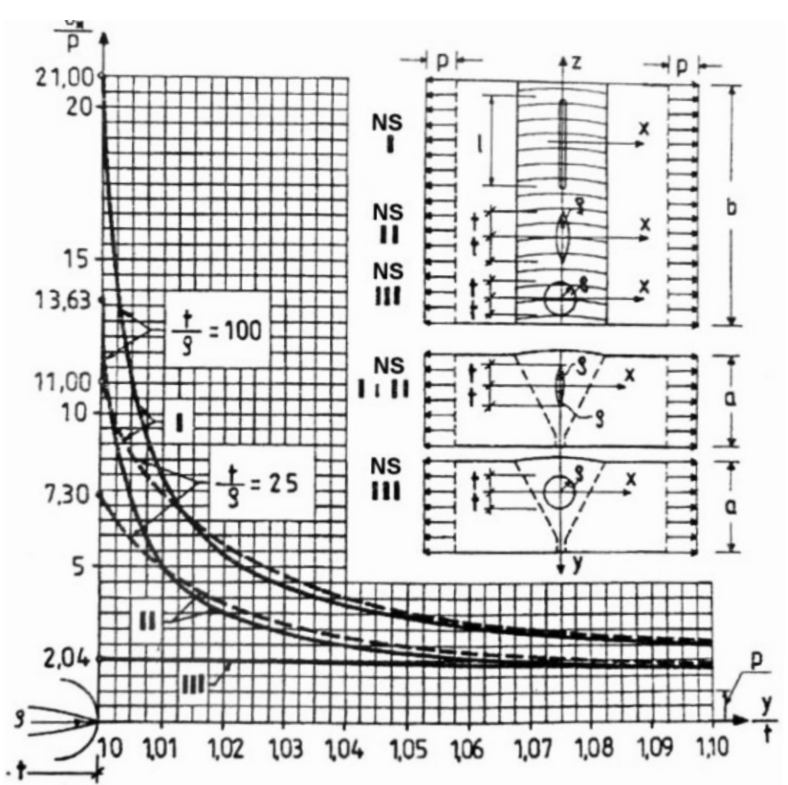

Rys. 3. Rozkład naprężeń $\sigma_{x}$ w pobliżu NS podłużnych - I, elipsoidalnych - II i kulistych - III

Fig. 3. Stress distribution $\sigma_{x}$ near weld imperfections longitudinal - I, ellipsoidal - II and globular - III

występują znaczne naprężenia własne rozciągające. Ponieważ prawdopodobieństwo powstania pęknięć jest największe właśnie $w$ tej strefie, nie można wykluczyć zapoczątkowania kruchego pękania konstrukcji nawet bez przyłożenia obciążenia zewnętrznego. W Polsce, w wyniku błędów konstrukcyjnych zniszczeniu uległ w Osobnicy k.Jasła, 8 stycznia 1987 r. przy temperaturze $-34^{\circ} \mathrm{C}$, drogowy most zespolony o dźwigarach eksploatowanych przez 17 lat, mimo braku obciążenia zewnętrznego - rysunek 4.

Na rysunku 5 według [7], podano zależność wytrzymałości doraźnej $R_{m}$ i wytrzymałości zmęczeniowej $Z_{\text {rj }}$ przy cyklu rozciągających naprężeń tętniących oraz przy cyklu wahadłowym. Z uwagi na fakt, że $Z_{\mathrm{rj}}<\mathrm{R}_{\mathrm{m}}$ to każda NS zewnętrzna i wewnętrzna spoiny stać się może inicjatorem pęknięcia zmęczeniowego lub kruchego.

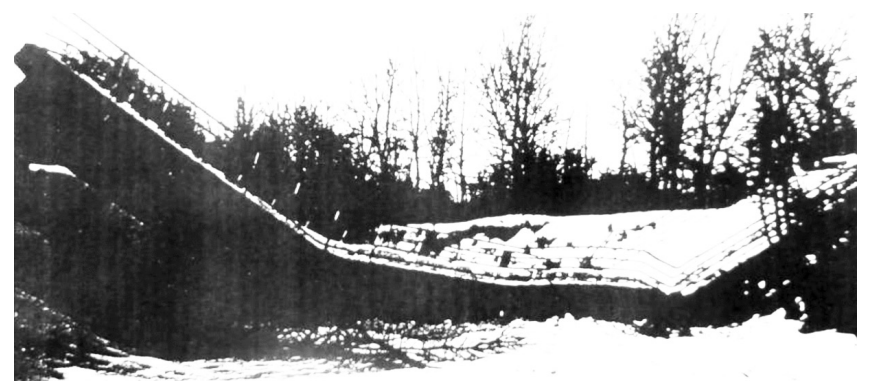

Rys. 4. Zniszczony most drogowy w Osobnicy k.Jasła Fig. 4. Destroyed road bridge in Osobnica near Jaslo

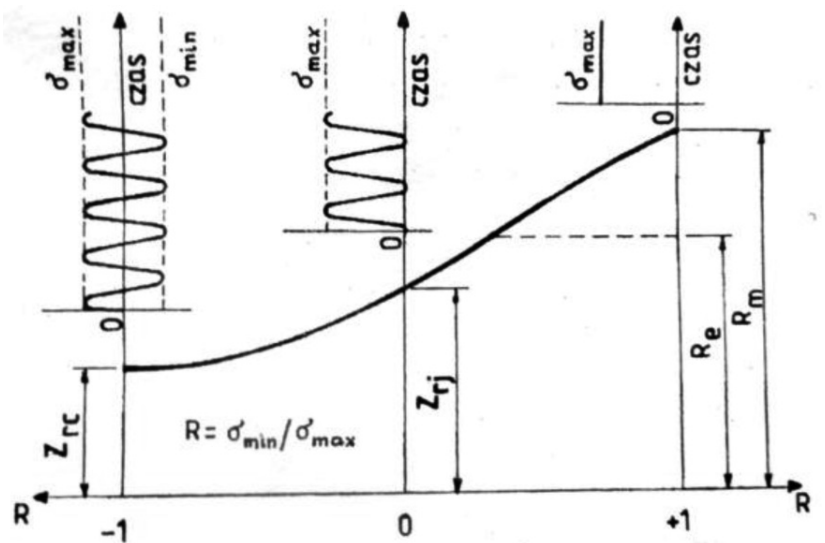

Rys. 5. Wytrzymałości początkowe i zmęczeniowe stali Fig. 5. Initial and fatique strength of steel 


\section{Jakość spoin czołowych w najstarszych mostach w Polsce}

Każda wada spoiny stać się może przyczyną pęknięcia, a więc utratą nośności konstrukcji. Zagadnienie staje się ważne w świetle wyników badań rentgenograficznych eksploatowanych mostów kolejowych [8]. Na ogólną liczbę 155 przebadanych mostów kolejowych w 34 (22\%) stwierdzono pęknięcia w spawanych złączach doczołowych, przy czym 33 obiekty to konstrukcje wybudowane w latach 1936-1960. Pęknięcia stwierdzono na 437 rentgenogramach, co stanowi 2,8\% ogólnej liczby 15875 przebadanych złączy. Wielokrotne badania złączy doczołowych z pęknięciami nie wykazały ich rozwoju ani powstawania nowych pęknięć. W celu wyjaśnienia tej okoliczności w artykule przedstawiono stan jakościowy spoin czołowych oraz ich analizę naprężeniową w dziewięciu najstarszych mostach spawanych w Polsce. Wykaz tych konstrukcji przedstawiono w tablicy I. Jest to most drogowy przez rzekę Słudwię pod Łowiczem (nr 1 - rys. 6) oraz osiem mostów kolejowych o numerach od I do VIII usytuowanych na 4 liniach. Mosty mają rozpiętości od 9,00 do 32,40 m. Poddawano je badaniom z różną częstością od 1 do 5 badań, w latach 1958-1984. Tylko most nr VIII był pierwotnie badany przez Niemców w roku 1936.

Łącznie wykonano 746 zdjęć złączy doczołowych, w tym prawie jednakowa ich liczba przypada na strefę ściskania i rozciągania, odpowiednio 350 i $396 \mathrm{rtg}$. Na rysunku 7 przedstawiono graficznie w ujęciu liczbowym, zestawienie przebadanych złączy doczołowych w poszczególnym moście z podziałem na poziomy jakości dopuszczalne (histogram górny) i niedopuszczalne (histogram dolny) według wymogów PN-EN ISO 5817:2014. Na histogramie dolnym podano również liczbę rentgenogramów z pęknięciami spoin w danym moście. Największa procentowo liczba złączy doczołowych poziomu jakości D i >D występuje w moście drogowym 1 na rzece Słudwi i w moście kolejowym I przez rzekę Sierpienicę. Procentowa zawartość rentgenogramów spoin poziomu jakości $\mathrm{D}$ i >D w tych mostach wynosi odpowiednio $34,7 \%$ i $32,0 \%[8,9]$.

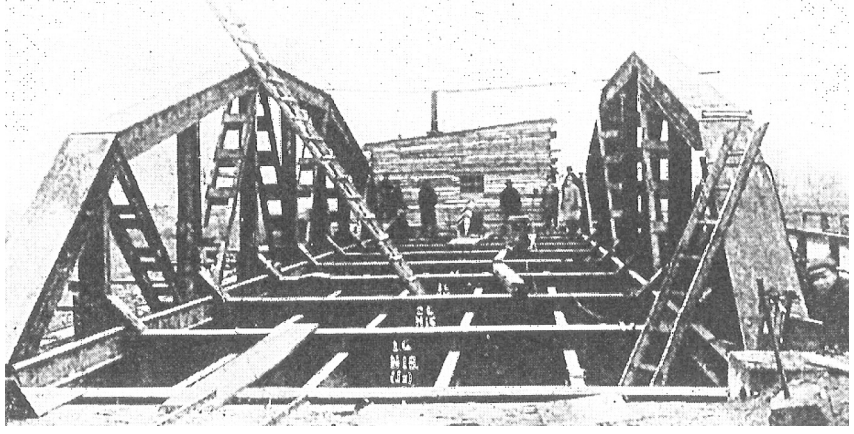

Rys. 6. Konstrukcja mostu w czasie budowy w 1929 roku Fig. 6. The construction of the bridge during building in 1929

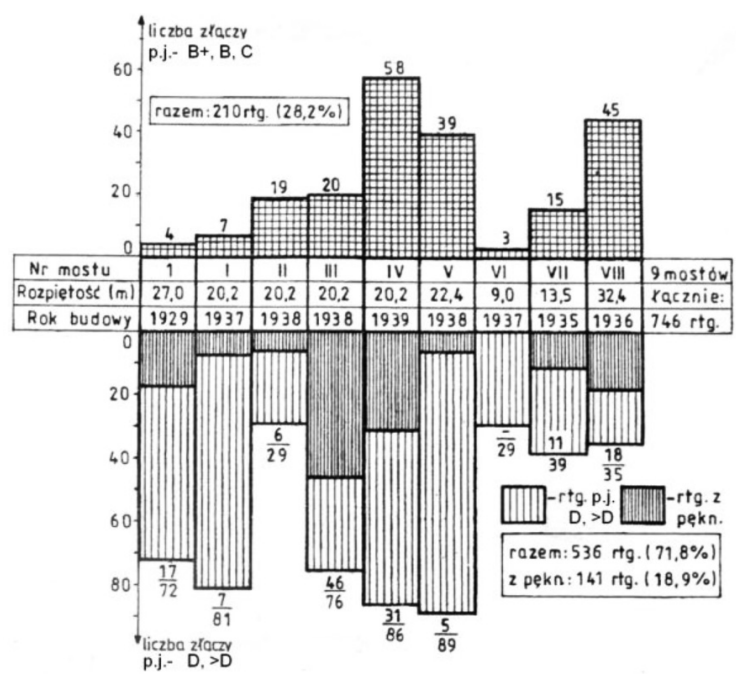

Rys. 7. Histogram poziomów jakości złączy doczołowych i liczba rentgenogramów z pęknięciami spoin w danym moście (wartość w liczniku)

Fig. 7. Histogram of butt joints quality levels and the number of radiograms with weld cracks in the bridge (the value in the numerator)

Tablica I. Dane badań radiograficznych mostów

Table I. Data of X-ray research of bridges

\begin{tabular}{|c|c|c|c|c|c|c|c|}
\hline \multirow{2}{*}{ Usytuowanie na linii } & \multirow{2}{*}{ Nr mostu } & \multirow{2}{*}{$\begin{array}{c}\text { Rok } \\
\text { budowy }\end{array}$} & \multirow{2}{*}{ Rok badań } & \multicolumn{2}{|c|}{ Liczba badanych } & \multicolumn{2}{|c|}{ Liczba } \\
\hline & & & & Dźwigarów & Złączy & Rtg. & Pęknięć \\
\hline 1 & 2 & 3 & 4 & 5 & 6 & 7 & 8 \\
\hline Kutno-Łowicz & 1 & 1929 & 1958 & 2 & 66 & 76 & 17 \\
\hline Nasielsk-Toruń & $\begin{array}{l}\text { I } \\
\text { II } \\
\text { III } \\
\text { IV }\end{array}$ & $\begin{array}{l}1937 \\
1938 \\
1938 \\
1939\end{array}$ & $\begin{array}{c}1958,1971 \\
1958,1971 \\
1958,1971 \\
1958\end{array}$ & $\begin{array}{l}4 \\
2 \\
4 \\
6\end{array}$ & $\begin{array}{l}40 \\
24 \\
48 \\
72\end{array}$ & $\begin{array}{c}88 \\
48 \\
96 \\
144\end{array}$ & $\begin{array}{c}8 \\
6 \\
48 \\
39\end{array}$ \\
\hline Łódź-Dębica & V & 1938 & 1963,1970 & 6 & 64 & 128 & 5 \\
\hline Warszawa-Łowicz & VI & 1937 & 1950, 1967, 1979 & 8 & 16 & 32 & - \\
\hline Poznań-Szczecin & $\begin{array}{l}\text { VII } \\
\text { VIII }\end{array}$ & $\begin{array}{l}1935 \\
1936\end{array}$ & $\begin{array}{c}1971,1984 \\
1936,1958,1962 \\
1969,1983\end{array}$ & $\begin{array}{l}7 \\
4\end{array}$ & $\begin{array}{l}19 \\
10\end{array}$ & $\begin{array}{l}54 \\
80\end{array}$ & $\begin{array}{c}5 \\
36\end{array}$ \\
\hline & zem & & 20 badań & 43 & 359 & 746 & $164^{*}$ \\
\hline
\end{tabular}




\section{Stan naprężeniowy spoin}

W celu oszacowania trwałości użytkowej mostów przeprowadzono analizę naprężeń w złączach doczołowych z pęknięciami, które stwierdzono w 8 mostach. Wyniki analizy podano w tablicy II. Dokonano obliczenia wartości naprężeń charakterystycznych występujących w spoinach czołowych (w osi nakładek i przykładek) oraz poza nakładkami w blasze pasowej lub środnikach (wartości w mianowniku).

Obliczenia wykonano zgodnie z PN-82/S-10052 i PN85/S-10030 - jak przy sprawdzaniu na zmęczenie, tj. przy obciążeniach charakterystycznych ze współczynnikiem dynamicznym. W kolumnie 3 podano wartość naprężeń nominalnych od stałego obciążenia mostu, a w kolumnie 4 od obciążenia stałego i obciążeń normowych taborem, z uwzględnieniem wpływów dynamicznych. Naprężenia te wyznaczono od podstawowego układu obciążeń, przyjmując klasę obciążenia $\mathrm{k}+2$. W kolumnie 5 zestawiono wartości naprężeń od obciążenia stałego i ruchomego lokomotywą ET-21, z uwzględnieniem wpływów dynamicznych. Natomiast dla mostu VIII były to dwa parowozy Pt 31.

W kolumnie 6 podano pomierzone tensometrycznie wartości naprężeń:

- w moście nr 1, od dwóch samochodów, o naciskach kół - oś przednia 5,3 i 4,7 ton, a oś tylna 13,3 i 14,1 ton;

- w moście nr VIII od 2 parowozów Pt 31 z tendrami 32D29 Natomiast w kolumnie 7 podano wartości ilorazów naprężeń $\sigma_{\text {ekspl }} / \sigma_{\text {norm. }}$.

Tablica II. Schematy dźwigarów i naprężenia normalne od obciążeń charakterystycznych w spoinach czołowych (wartości w liczniku) oraz poza nakładkami (wartości w mianowniku) i $\lambda=\sigma_{\text {ekspl }} / \sigma_{\text {norm }}$

Table II. Schemes of carrying girders and normal stresses of characteristic loads in the butt welds (value in the numerator) and off overlays (values in the denominator) and $\lambda=\sigma_{\text {ekspl }} / \sigma_{\text {norm }}$

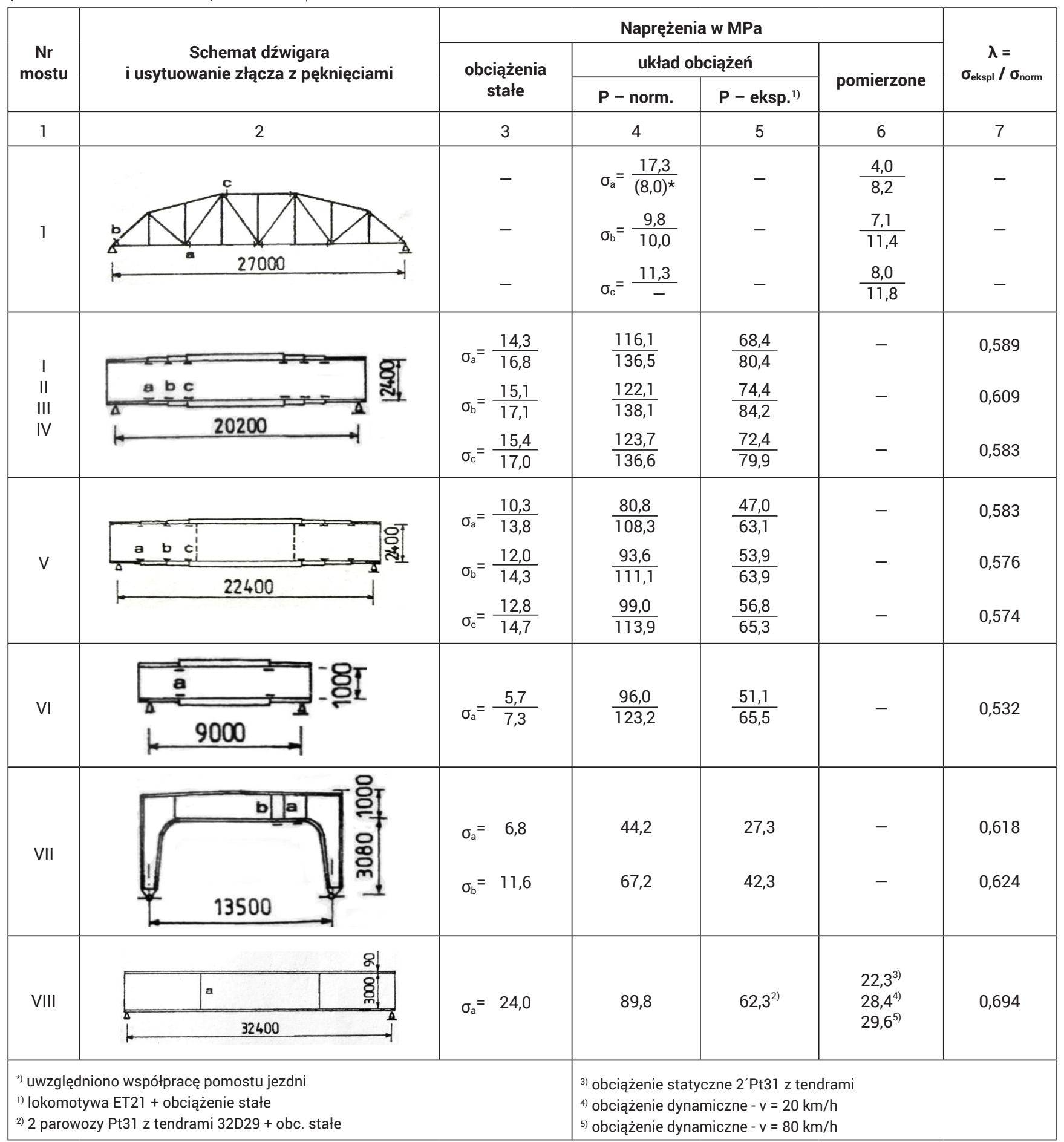




\section{Badania zmęczeniowe spoin czołowych}

W ramach kompleksowej oceny żywotności złączy doczołowych występujących w starych konstrukcjach przeprowadzono laboratoryjne badania zmęczeniowe czterech grup złączy przedstawionych na rysunku 8. Proste regresji dotyczą:

- badań próbek „a” - ze spoinami czołowymi poziomu jakości > D i starzonymi w sposób naturalny przez 45 lat, dla których wartość nieograniczonej wytrzymałości zmęczeniowej (NWZ) wynosi $\mathrm{Z}_{\mathrm{rj}}=101 \mathrm{MPa}$;

- badań próbek "b" - ze spoinami czołowymi poziomu jakości B+, B i C, dla których NWZ ma wartość $Z_{\mathrm{rj}}=125 \mathrm{MPa}$;

- badań próbek "c" - ze spoinami czołowymi obarczonymi pęknięciami wewnętrznymi o uzyskanej z badań wartości $\mathrm{NWZ} \mathrm{Z}_{\mathrm{ri}}=90 \mathrm{MPa}$;

- badań próbek "d" - ze spoinami przykrytymi jednostronnymi nakładkami rombowymi o wartości $Z_{\mathrm{rj}}=79 \mathrm{MPa}$.

Nieograniczona wytrzymałość zmęczeniowa spoin czołowych z pęknięciami wewnętrznymi i spoin z jednostronnymi nakładkami rombowymi stanowi odpowiednio 71,7 i 63,2\% wytrzymałości zmęczeniowej spoin „zdrowych" [8]. Po liczbie cykli obciążenia powyżej $1,1 \cdot 10^{6}$ nakładki na spoinach w większym stopniu osłabiają ich wytrzymałość niż pęknięcia w spoinach (por. rys. 5 i 8 ).

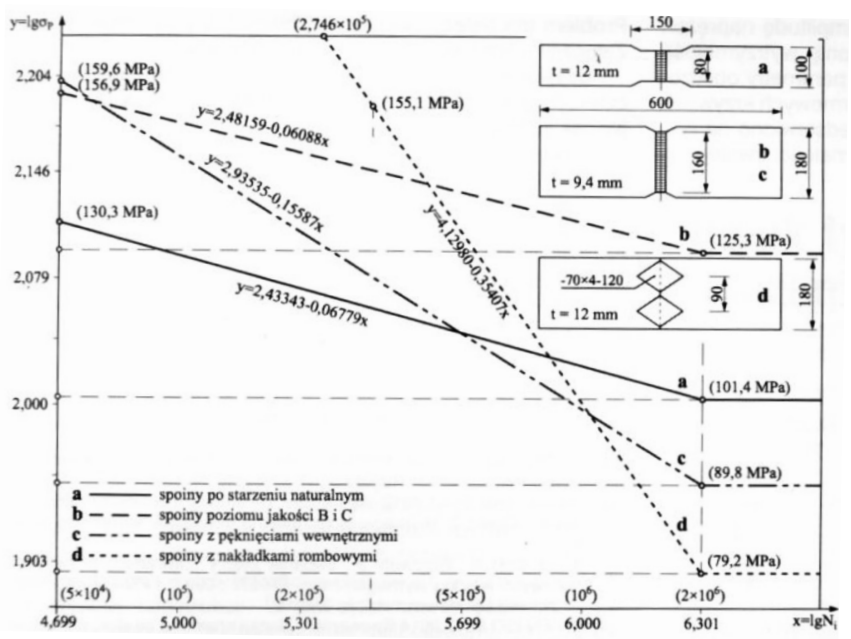

Rys. 8. Zestawienie prostych regresji 4 rodzajów złączy ze spoinami czołowymi

Fig. 8. Collection of regression lines for 4 types of joints with butt welds

\section{Podsumowanie}

W badaniach rentgenograficznych, 9 najstarszych mostów spawanych w Polsce, stwierdzono bardzo niską jakość spoin złączy doczołowych. 71,8\% badanych odcinków złączy doczołowych ma niezgodności spawalnicze poziomu jakości D i większe, a na 141 rentgenogramach stwierdzono pęknięcia spoin. Wielokrotne badania nie stwierdziły rozwoju tych pęknięć. Według S. Kocandy [10]: „naprężenie inicjujące pęknięcie jest mniejsze od naprężenia koniecznego do rozwoju pęknięcia”.

Praktycznie we wszystkich złączach doczołowych analizowanych mostów, obliczone i pomierzone naprężenia eksploatacyjne nie przekraczają określonej doświadczalnie nieograniczonej wytrzymałości zmęczeniowej $Z_{\mathrm{rj}}$ spoin tych złączy. Wyjątek stanowi styk pasowy „b" mostów I-IV na linii Nasielsk-Toruń, w których przekroczenie wartości $Z_{\mathrm{rj}}$ od naprężeń eksploatacyjnych jest nieznaczne i wynosi 3,2\%.

Przedstawione w artykule zachowanie się złączy doczołowych z pęknięciami w omawianych mostach oraz ich analiza obliczeniowa i wyniki badań zmęczeniowych, potwierdziły fakt braku rozwoju tych pęknięć. Omawiane mosty kolejowe nr I $\div$ VIII mogą być dalej bezpiecznie eksploatowane.

\section{Literatura}

[1] Wiśniewski D., Majka M., Bień J.: Ocena nośności mostów w okresie ich eksploatacji - doświadczenia krajowe i zagraniczne. Inżynieria i Budownictwo, nr 7-8/2013.

[2] Kühn B., et al.: Assesment of existing steel structures: recommendations for estimation of remaining fatigue life. JRC Scientific and technical Report no. 43401. European Commision, Joint Research Centre, Luxemburg 2008.

[3] Butnicki S.: Spawalność i kruchość stali. WNT, Warszawa 1975.

[4] Rykaluk K.: Pęknięcia w konstrukcjach stalowych. DWE, Wrocław 1999.

[5] Wichtowski B., Hołowaty J.: Właściwości stali w najstarszych spawanych mostach kolejowych w Polsce w świetlne badań. Inżynieria i Budownictwo, $\mathrm{nr}$ 5/2009.
[6] Wichtowski B., Hołowaty J.: Badania udarnościowe stali zlewnej mostów kolejowych, Inżynieria i Budownictwo, nr 1/2014.

[7] Newmann A.: Schweisstechnisches Handbuch für Konstrukteure Teil 1. VEB Verlag Technik, Berlin 1990.

[8] Wichtowski B.: Wytrzymałość zmęczeniowa spawanych złączy doczołowych w stalowych mostach kolejowych. Prace naukowe PS nr 572, Szczecin 2002.

[9] Bogucki W.: Badania pracy mostu na rzece Słudwi. Inżynieria i Budownictwo, $\mathrm{nr}$ 10/1962.

[10] Kocanda S.: Zmęczeniowe pękanie metali. WNT, Warszawa 1985. 